\title{
Salinity does not alter the effectiveness of menthol as an anesthetic and sedative during the handling and transport of juvenile fat snook (Centropomus parallelus)
}

\author{
L. C. O. 'R. Sepulchro ${ }^{a}$, M. A. G. Carvalho and L. C. Gomes ${ }^{a *}$ \\ aLaboratório de Ictiologia Aplicada, Universidade Vila Velha - UVV, Rua Comissário José Dantas de Melo, 21, \\ Boa Vista, CEP 29101-770, Vila Velha, ES, Brazil \\ *e-mail: levy.gomes@uvv.br
}

Received: March 13, 2015 - Accepted: July 2, 2015 - Distributed: August 31, 2016

(With 2 figures)

\begin{abstract}
The effectiveness of menthol as anesthetic and sedative for fat snook (Centropomus parallelus) was tested at different salinities. In the first experiment, the fish were exposed to different concentrations of menthol $\left(25,37\right.$ and $\left.50 \mathrm{mg} \mathrm{L}^{-1}\right)$ in water at different salinities $(0,17$ and $36 \mathrm{ppt})$. In the second experiment, the fish were transported for 10 hours in water with menthol at concentrations of $0,3.7$ and $7.4 \mathrm{mg} \mathrm{L}^{-1}$ under different salinities. $\mathrm{Na}^{+}$and $\mathrm{K}^{+}$ions from fish body and water were analyzed after transport. The optimal concentrations of menthol for a short handling period and surgical induction was 37 and $50 \mathrm{mg} \mathrm{L}^{-1}$, respectively, and these values were independent of salinity. After transport, neither mortality nor significant changes in ammonia or dissolved oxygen were observed between treatments at the different salinities. The nitrite levels were lower in freshwater than in brackish and saltwater, but did not change with mentol. The total body levels of $\mathrm{Na}^{+}$increased with the salinity increase. Menthol is an effective anesthetic for handling of juvenile fat snook at different salinities. Menthol did not influence the measured water parameters and body ions, and it is not necessary for the transport of fat snook.
\end{abstract}

Keywords: anesthesia, stress, fish, body ions, sedation.

\section{Salinidade não altera a eficácia de mentol como um anestésico e sedativo durante a manipulação e transporte de juvenis de robalo peva (Centropomus parallelus)}

\begin{abstract}
Resumo
A eficácia de mentol como anestésico e sedativo para o robalo peva (Centropomus parallelus) foi testada em diferentes salinidades. No primeiro experimento, os peixes foram expostos a diferentes concentrações de mentol $\left(25,37\right.$ e $\left.50 \mathrm{mg} \mathrm{L}^{-1}\right)$ em diferentes salinidades na água $(0,17$ e $36 \mathrm{ppt})$. No segundo experimento, os peixes foram transportados por 10 horas em água com mentol nas concentrações de $0,3,7$ e 7,4 $\mathrm{mg} \mathrm{L}^{-1}$ sob diferentes salinidades. $\mathrm{O} \mathrm{Na}^{+}$e $\mathrm{K}^{+}$do corpo do peixe e a água foram analisados após o transporte. As concentrações ideais de mentol para um período curto de manipulação e indução cirúrgica foi 37 e $50 \mathrm{mg} / \mathrm{L}$, respectivamente, sendo esses valores independentes da salinidade da água. Após o transporte, não foi verificado mortalidades e nem alterações significativas nos níveis da amônia e oxigênio dissolvido entre os tratamentos para as diferentes salinidades. Os níveis de nitrito foram mais baixos em água doce do que em água salobra e água salgada, mas não se alterou com o mentol. Os níveis corporais de $\mathrm{Na}^{+}$e $\mathrm{K}^{+}$aumentaram com o aumento da salinidade. Mentol é um eficaz anestésico para manipulação de robalo peva juvenil em diferentes salinidades. Mentol não influenciou os parâmetros de medição de água e íons do corpo, e não é necessário para o transporte de robalo peva.
\end{abstract}

Palavras-chaves: anestesia, estresse, peixes, ions corporais, sedação.

\section{Introduction}

The fat snook, Centropomus parallelus Poey, 1860 is widely distributed along the central South Atlantic coast and exhibits significant potential for aquaculture because it adapts well to captivity and is resistant to cage and pond rearing systems and variations in water salinity. It also has high market value because of the quality of its meat (Tsuzuki et al., 2007; Cerqueira, 2010).

Among the most common practices in fish farming, which include biometrics, transportation, extrusion of gametes and marking, anesthetization of fish is 
an important approach for facilitating manipulation and for reducing stress and injuries in fish (Ross and Ross, 1999). Anesthetization therefore ensures that the fish are handled correctly (Inoue et al., 2003, 2005; Small, 2003).

Natural oils are becoming increasingly used as anesthetics due to their low toxicity and risks to operators (Façanha and Gomes, 2005; Tondolo et al., 2013). In this context, menthol has been used as an anesthetic for marine invertebrates and fish (Ross and Ross, 1999; Simões and Gomes, 2009). Similar to other natural oil-derived anesthetics (Small, 2003; Simões et al., 2011; Souza et al., 2012), menthol has several features and qualities that make it suitable for use as a fish anesthetic (Façanha and Gomes, 2005).

Many teleosts living in estuaries are classified as euryhaline organisms, which can easily adapt to salt, fresh or brackish water (Carneiro et al., 2007). When fish are moved from salt to freshwater, physiological adaptations occur in two stages. The first step is called the "adaptive" stage, in which plasma osmolarity is reduced due to the loss of inorganic ions and the gain of osmotic water. During the second "regulatory" stage, the osmolarity and plasma ion concentrations increase to normal levels and are regulated and maintained within the limits of homeostasis (Prodocimo and Freire, 2006). These physiological adaptations are related to the absorption and secretion of salts and water that help maintain the body tissues (Prodocimo and Freire, 2006; Carneiro et al., 2007). Anesthetics can exhibit altered efficiencies during the adaptive stage depending on the environment of the fish; therefore, it is necessary to develop strategies for the use of anesthetics during the handling and transport of fish that have been reared in different salinities. Thus, the aim of this study was to evaluate the effectiveness of menthol as an anesthetic and sedative over a range of different salinities during the handling and transport of fat snook.

\section{Material and Methods}

\subsection{Acquisition of animals and acclimation}

Juvenile fat snook $(n=450-90$ for the first experiment and 360 for the second experiment, $1.6 \pm 0.4 \mathrm{~g}$ and $4.8 \pm 0.4 \mathrm{~cm}$; mean \pm SD) were obtained from the Pandini Mariculture (São Mateus, ES, Brazil) and subsequently transported to laboratory. Seventy-five fish were added to six $45-\mathrm{L}$ aquariums, each one containing $30 \mathrm{~L}$ seawater (salinity, $36 \mathrm{ppt}$ ) and acclimated for 1 week. After this period, the salinity of each aquarium was adjusted to 0,17 or $36 \mathrm{ppt}$ (two aquariums per salinity level). To achieve a salinity of $17 \mathrm{ppt}$, seawater was mixed with chlorine-free freshwater (considered to be brackish water), and to achieve a salinity of 0 ppt, only chlorine-free freshwater (considered to be freshwater) from the municipal water supply system was used. The salinity level of the brackish and freshwater aquarium was gradually attained by replacing one-seventh of a tank volume of seawater with freshwater daily until the desired salinity level was achieved (Tsuzuki et al.,
2007). The fish were maintained at the respective salinity level for 14 days prior to testing. Siphoning was performed on each aquarium every two days, and the water was completely exchanged once per week.

Before the experiment, the water quality in each tank was measured three times per week to monitor conductivity, salinity, temperature and dissolved oxygen, with a digital multiparameter meter (YSI professional PRO, YSI Inc., Yellow Spring, Ohio, USA). The water quality parameters measured during the period of acclimatization were as follows: freshwater conductivity: $1.51 \pm 0.23 \mathrm{mS} \mathrm{cm}^{-1}$, salinity: $0.25 \pm 0.20 \mathrm{ppt}$, temperature: $23.82 \pm 0.38^{\circ} \mathrm{C}$, dissolved oxygen: $7.58 \pm 0.12 \mathrm{mg} \mathrm{L}^{-1}$; brackish water conductivity: $29.63 \pm 0.63 \mathrm{mS} \mathrm{cm}^{-1}$, salinity: $17.72 \pm 1.21 \mathrm{ppt}$, temperature: $23.9 \pm 0.29{ }^{\circ} \mathrm{C}$, dissolved oxygen: $7.04 \pm 0.61 \mathrm{mg} \mathrm{L}^{-1}$; and seawater conductivity: $53.87 \pm 1.11 \mathrm{mS} \mathrm{cm}^{-1}$, salinity: $36.17 \pm 0.42 \mathrm{ppt}$, temperature: $24.05 \pm 0.40{ }^{\circ} \mathrm{C}$, and dissolved oxygen: $5.59 \pm 0.17 \mathrm{mg} \mathrm{L}^{-1}$.

\subsection{Experiment 1 - anesthesia}

In the first experiment, the optimal concentration of menthol (i.e., the lowest concentration that induced the desired stage of anesthesia) for handling was set for each salinity level. The tests were performed in static 4-L aquariums, each of which contained $3 \mathrm{~L}$ of water. A 10-L plastic tank containing $8 \mathrm{~L}$ of water with constant aeration was used for fish recovery.

Menthol crystals (Via Farma, SP) were dissolved in $99.8 \%$ ethanol to produce a $100 \mathrm{mg} \mathrm{L}^{-1}$ stock solution. At each salinity level, three different concentrations of menthol $\left(25,37\right.$ and $\left.50 \mathrm{mg} \mathrm{L}^{-1}\right)$ were tested to assess the time to anesthesia induced by each anesthetic concentration. Ten fish were individually exposed to anesthetic to each one of the 9 treatments (3 salinity versus 3 anesthetic concentration; $\mathrm{n}=90$ fish), to obtain measurements of the induction time for each stage of anesthesia. After 10 minutes of exposure to the anesthetic (Gomes et al., 2001), the fish were transferred to the recovery tank for monitoring. The stages of anesthesia evaluated were the total loss of equilibrium (brief handling) and minimal opercular movement (surgical anesthesia) (Stoskopf, 1993). The fish were considered recovered when they achieved equilibrium and began swimming actively.

Additionally, a control experiment with freshwater adapted fish $(\mathrm{n}=10)$ was performed using aquaria that contained only ethanol at concentration of $0.5 \mathrm{~mL} \mathrm{~L}^{-1}$, which is equivalent to the dilution used for the greatest tested menthol concentration $\left(50 \mathrm{mg} \mathrm{L}^{-1}\right)$. All experimental procedures for this test were similar to the one used with the anesthetic.

The results from each stage of anesthesia were subjected to two-way ANOVA (salinity and menthol concentration) and Tukey's test $(\mathrm{P}<0.05)$. For cases in which the results from two or more anesthetic concentrations were similar in both time-to-anesthesia and recovery time, the lower concentration was selected as the optimal concentration, as lower concentrations are less costly for end users. 


\subsection{Experiment 2 - transport}

In the second experiment, the fish $(n=360 ; 120$ from each salinity) were transported in plastic bags with a capacity of $2 \mathrm{~L}$. The bags contained $1 \mathrm{~L}$ of water, were inflated with oxygen and then added to a styrofoam box. The fish ( $n=10$ per bag) were subjected to different salinity levels $(0,17$ and $36 \mathrm{ppt})$ and 10 hours of transport by driving in a pavement road. The treatments were as follows: control (no anesthetic), positive control (containing an amount of ethanol equivalent to the highest concentration used to dilute the tested anesthetic) and 3.7 or $7.4 \mathrm{mg} \mathrm{L}^{-1}$ menthol (10 and $20 \%$ of the optimum concentration obtained in the first experiment). The experiments were performed with 3 bags (replicate) for each combination of treatment and salinity, totaling 36 bags. The water temperature before transport was $26.7 \pm 1.5^{\circ} \mathrm{C}$.

At the end of the experimental transport period, the bags were opened, and the dissolved oxygen and temperature of the water were immediately measured using a multiparameter meter (YSI professional PRO, YSI Inc., Yellow Spring, Ohio, USA). A water sample was collected from each bag for total ammonia and nitrite testing according to the APHA (1998) guidelines. To determine the body levels of $\mathrm{Na}^{+}$and $\mathrm{K}^{+}, 3$ fish were separated from each bag, placed individually into $15-\mathrm{mL}$ tubes and then sacrificed by cooling on ice. The samples were weighed, measured, individually immersed in hydrochloric acid and allowed to dissolve in an oven at $80^{\circ} \mathrm{C}$ for 24 hours, according to the criterion for fish previously detailed by Gomes et al. (1999). Readings were obtained using a flame photometer.

After transportation, the anesthesia stage was observed in fish. The remaining fish from all bags of each treatment was added to a single $30 \mathrm{~L}$ aquarium ( 9 aquariums, one for each treatment) at the same salinity and temperature of the transportation water to monitor the mortality rate for $96 \mathrm{~h}$.
The water quality and body ion results were compared by two-way ANOVA (salinity and treatment) and Tukey's tests $(\mathrm{P}<0.05)$.

\section{Results}

\subsection{Experiment 1 -anesthesia}

No mortality was observed during the test period and fish from all concentrations and salinity did not show any anesthetic stage. Ethanol alone did not induce fish to any tested anesthetic stage. At a menthol concentration of $25 \mathrm{mg} \mathrm{L}^{-1}$ in freshwater, $10 \%$ fish did not exhibit a total loss of equilibrium, and $20 \%$ fish did not exhibit minimal opercular movements. In brackish water with the same menthol concentration, $10 \%$ fish did not exhibit a total loss of equilibrium, and 50\% fish did not exhibit minimal opercular movement; however, in seawater, 50\% fish did not exhibit minimal opercular movement. A menthol concentration of $50 \mathrm{mg} \mathrm{L}^{-1}$ induced anesthesia in fish of all stages, whereas a concentration of $37 \mathrm{mg} \mathrm{L}^{-1}$ induced anesthesia in all. The exception was $10 \%$ of fish which did not exhibit minimal opercular movements in brackish and in a saltwater (see Table 1).

The fish anesthetized with $50 \mathrm{mg} \mathrm{L}^{-1}$ reached the stage of complete loss of equilibrium and minimal opercular movements in significantly less time than did the fish exposed to $25 \mathrm{mg} \mathrm{L}^{-1}$ of anesthetic at all salinity levels. At all menthol concentrations, there was no difference in the time required to reach the total loss of equilibrium among the salinities. However, minimal opercular movement was achieved more rapidly in fish exposed to $25 \mathrm{mg} \mathrm{L}^{-1}$ menthol in freshwater compared with fish exposed to $25 \mathrm{mg} \mathrm{L}^{-1}$ menthol in brackish water and saltwater. The recovery time was lower in fish exposed to $50 \mathrm{mg} \mathrm{L}^{-1}$ menthol in

Table 1. Time (in seconds) to the induction of different stages of anesthesia in the fat snook (Centropomus parallelus) upon exposure to different concentrations of menthol $\left(\mathrm{mg} \mathrm{L}^{-1}\right)$ for 10 minutes. Capital letters in each line indicate significant differences among salinities at the same anesthetic concentration $(\mathrm{P}<0.05)$. Lowercase letters indicate significant differences in different anesthetic concentrations at a given salinity $(\mathrm{P}<0.05)$, as indicated by two-way ANOVA and Tukey's test $(\mathrm{P}<0.05)$. The results shown are the mean values \pm standard deviation.

\section{BEHAVIORAL EVENTS (SECONDS)}

\begin{tabular}{|c|c|c|c|}
\hline Menthol (mg L $\left.\mathbf{L}^{-1}\right)$ & Total loss of equilibrium & $\begin{array}{c}\text { Minimal opercular } \\
\text { movement }\end{array}$ & Recovery \\
\hline \multicolumn{4}{|l|}{ Freshwater } \\
\hline 25 & $402 \pm 197^{\mathrm{aA} 1}$ & $271 \pm 44^{\mathrm{abB} 2}$ & $147 \pm 42^{\mathrm{aA}}$ \\
\hline 37 & $138 \pm 69^{\mathrm{bA}}$ & $331 \pm 133^{\mathrm{aA}_{\mathrm{A}}}$ & $161 \pm 70^{\mathrm{bA}}$ \\
\hline 50 & $96 \pm 24^{\mathrm{bA}}$ & $195 \pm 30^{\mathrm{bA}}$ & $216 \pm 87^{\mathrm{bAB}}$ \\
\hline \multicolumn{4}{|l|}{ Brackish water } \\
\hline 25 & $402 \pm 119^{\mathrm{aAl}}$ & $558 \pm 62^{\mathrm{aA} 3}$ & $146 \pm 28^{\mathrm{aA}_{\mathrm{A}}}$ \\
\hline 37 & $182 \pm 104^{\mathrm{bA}}$ & $365 \pm 72^{\mathrm{bAl}}$ & $184 \pm 38^{\mathrm{abA}}$ \\
\hline 50 & $113 \pm 93^{\mathrm{bA}}$ & $245 \pm 130^{\mathrm{cA}}$ & $205 \pm 50^{\mathrm{bB}}$ \\
\hline \multicolumn{4}{|l|}{ Saltwater } \\
\hline 25 & $359 \pm 131^{\mathrm{aA}}$ & $495 \pm 30^{\mathrm{aA} 3}$ & $181 \pm 68^{\mathrm{aA}}$ \\
\hline 37 & $216 \pm 154^{\mathrm{bA}}$ & $332 \pm 75^{\mathrm{bA} 1}$ & $175 \pm 50^{\mathrm{aA}}$ \\
\hline 50 & $119 \pm 51^{\mathrm{bA}}$ & $227 \pm 73^{\mathrm{cA}}$ & $264 \pm 69^{\mathrm{bA}}$ \\
\hline
\end{tabular}

${ }^{1}$ One fish did not reach this stage. ${ }^{2}$ Two fish did not reach this stage. ${ }^{3}$ Five fish did not reach this stage. 
brackish water than it was in fish exposed to $50 \mathrm{mg} \mathrm{L}^{-1}$ menthol in saltwater (see Table 1).

\subsection{Experiment 2 - transport}

There was no mortality after transportation and during the $96 \mathrm{~h}$ recovery period. The mean water temperature after transportation was $26.07 \pm 1.27$ with no significant difference among treatments. The ammonia concentrations of the water did not differ significantly regardless of salinity or treatment, with the exception of ethanol treatment in brackish water that presented a significative decrease in the ammonia levels. In freshwater, the ammonia concentration ranged between 3.82 and $5.19 \mathrm{mg} \mathrm{L}^{-1}$, whereas the levels in brackish water ranged between 3.33 and $5.98 \mathrm{mg} \mathrm{L}^{-1}$. In saltwater, the levels ranged between 3.81 and $4.66 \mathrm{mg} \mathrm{L}^{-1}$ (see Figure 1).
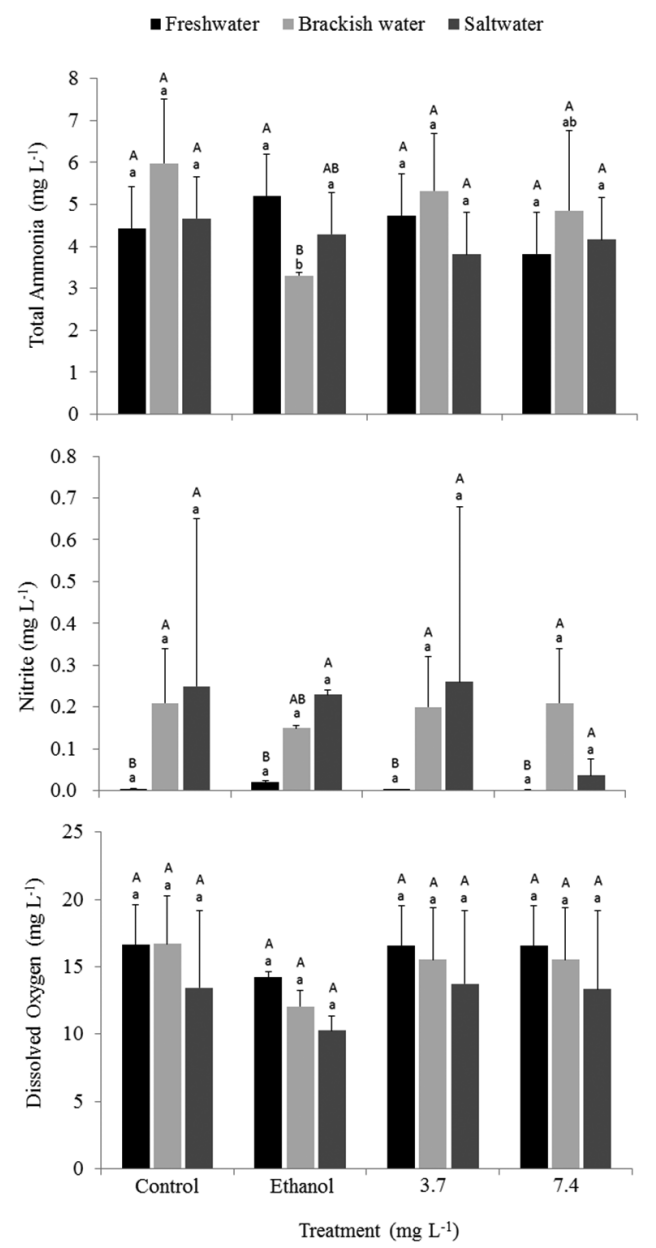

Figure 1. Total ammonia $\left(\mathrm{mg} \mathrm{L}^{-1}\right)$, nitrite $\left(\mathrm{mg} \mathrm{L}^{-1}\right)$ and dissolved oxygen $\left(\mathrm{mg} \mathrm{L}^{-1}\right)$ concentrations during the transport of fat snook at different salinities with different concentrations of menthol in the water. Capital letters indicate significant differences among salinities with the same treatment $(\mathrm{P}<0.05)$. Lowercase letters indicate significant differences at a given salinity among the different treatment $(\mathrm{P}<0.05)$, as indicated by two-way ANOVA and Tukey's test $(\mathrm{P}<0.05)$.
The nitrite levels increased with increasing salinity; however, there was no difference among the treatments. In freshwater, the nitrite concentrations ranged between 0.02 and $0.002 \mathrm{mg} \mathrm{L}^{-1}$, whereas in seawater and brackish water (which did not differ significantly among themselves), the nitrite concentrations ranged between 0.036 and $0.26 \mathrm{mg} \mathrm{L}^{-1}$ (see Figure 1).

The dissolved oxygen concentrations within the transport bags exhibited no significant changes, regardless of the salinity level or treatment. In freshwater, the oxygen concentrations ranged between 14.21 and $16.55 \mathrm{mg} \mathrm{L}^{-1}$, whereas the range in brackish water was between 12.05 and $16.71 \mathrm{mg} \mathrm{L}^{-1}$ and the range in saltwater was between 10.28 and $13.73 \mathrm{mg} \mathrm{L}^{-1}$ (see Figure 1).

The total body sodium concentrations did not differ significantly among the treatments; however, they increased as salinity increased within a given treatment. Specifically, the total body sodium values remained between 34.96 and $49.45 \mathrm{mEq} \mathrm{Na} \mathrm{kg}^{-1}$ in the freshwater samples, whereas they ranged between 55.76 and $66.33 \mathrm{mEq} \mathrm{Na} \mathrm{kg}^{-1}$ in the brackish water samples. In the saltwater samples, the total body sodium levels ranged between 71.42 and $88.86 \mathrm{mEq} \mathrm{Na} \mathrm{kg}^{-1}$. The total body potassium levels exhibited no significant changes among treatments or salinity levels, maintaining an average value of $106.3 \mathrm{mEq} \mathrm{K} \mathrm{kg}^{-1}$ in freshwater, $110.47 \mathrm{mEq} \mathrm{K} \mathrm{kg}^{-1}$ in brackish water and $113.61 \mathrm{mEq} \mathrm{K} \mathrm{kg}^{-1}$ in seawater (see Figure 2).

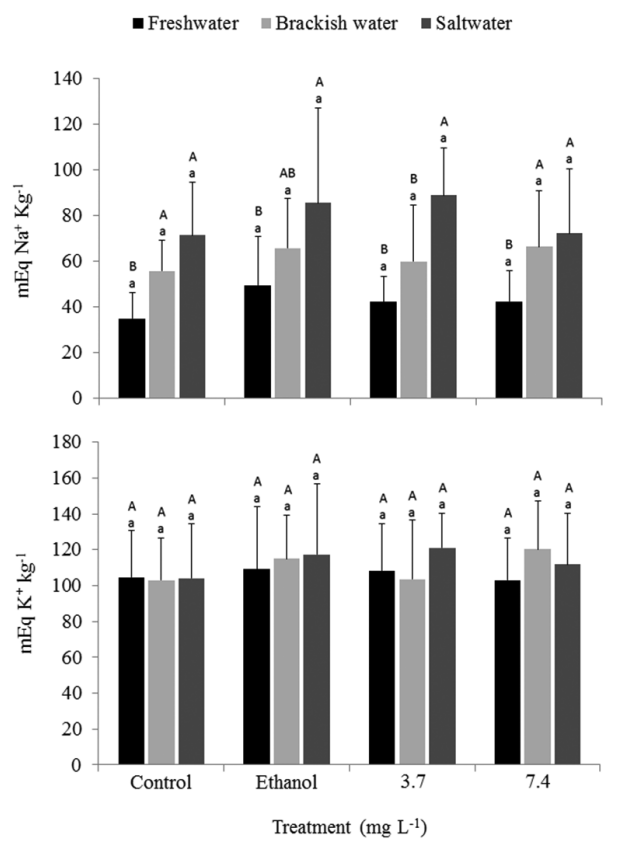

Figure 2. Total body sodium ( $\mathrm{mEq} \mathrm{Na} \mathrm{kg}^{-1}$ ) and potassium $\left(\mathrm{mEq} \mathrm{K} \mathrm{Kg}^{-1}\right.$ ) concentrations during the transport of fat snook at different salinities with different concentrations of menthol in the water. Capital letters indicate significant differences among salinities with the same treatment $(\mathrm{P}<0.05)$. Lowercase letters indicate significant differences at a given salinity under different treatments $(\mathrm{P}<0.05)$ as indicated by two-way ANOVA and Tukey's test $(\mathrm{P}<0.05)$. 


\section{Discussion}

\subsection{Experiment 1 - anesthesia}

When exposed to menthol concentrations above $37 \mathrm{mg}$ $\mathrm{L}^{-1}$, regardless of salinity, juvenile fat snook exhibit all of the stages of anesthesia described by Stoskopf (1993). The optimal anesthetic concentration of menthol for inducing surgical anesthesia in the juvenile fat snook was found to be $50 \mathrm{mg} \mathrm{L}^{-1}$, whereas that for brief handling was $37 \mathrm{mg} \mathrm{L}^{-1}$; these concentrations were found to be optimal regardless of salinity. Souza et al. (2012) reported different results using 30-g fat snook anesthetized with menthol and reported $150 \mathrm{mg} \mathrm{L}^{-1}$ to be the optimal concentration for anesthesia intended for brief management and biometrics. Simões and Gomes (2009) used 14-g Nile tilapia (Oreochromis niloticus) and reported 250 and $150-200 \mathrm{mg} \mathrm{L}^{-1}$ to be the optimal concentrations of menthol for surgical induction and brief handling, respectively. Façanha and Gomes (2005) reported the following optimal menthol concentrations for anesthetizing 23-g tambaqui (Colossoma macropomum): $150 \mathrm{mg} \mathrm{L}^{-1}$ for surgical induction and $100 \mathrm{mg} \mathrm{L}^{-1}$ for sedation for biometrics. Although several factors such as the water temperature, species, size and amount of fat can affect the extent of fish anesthesia (Ross and Ross, 1999), the significantly lower optimal menthol concentrations for the juvenile fat snook are predominantly attributed to its relatively smaller size. Small fish generally require a lower concentration of anesthetic than do larger fish to achieve the same stage of anesthesia. This trend was previously demonstrated in tambaqui that were anesthetized with eugenol (Roubach et al., 2005).

The last stage of complete induction of anesthesia was achieved significantly faster at a menthol concentration of $50 \mathrm{mg} \mathrm{L}^{-1}$ in seawater and brackish water. A different trend was observed for freshwater, where a relationship between concentration and time of induction was not clearly established due to the high variability in the results at a concentration of $37 \mathrm{mg} \mathrm{L}^{-1}$. Nonetheless, the induction times of different stages of anesthesia were similar for all of the salinities at a menthol concentration of $50 \mathrm{mg} \mathrm{L}^{-1}$. These results are contrary to findings described by Ghazilou et al. (2010), who reported that during the clove oil-induced anesthesia of Caspian salmon (Salmo trutta caspius), the induction times increased at higher water salinities, suggesting that the increased times were attributed to the "salting out" phenomenon. As an estuarine fish, the fat snook is well adapted to salinity changes. Additionally, in this study, the fish were previously acclimated at different salinities. Therefore, the main reason underlying the similar results obtained in terms of induction times among salinities was the regulatory capacity of the species under isosmotic conditions after an acclimation period at a specific salinity level.

\subsection{Experiment 2 - transport}

Ammonia is the predominant excretory product of fish. It is synthesized predominantly within the liver and is carried by the bloodstream to the gills, where it is excreted into the water (Ismiño-Orbe et al., 2003). When it is present in large quantities in the environment, ammonia can elicit adverse effects in fish, including degeneration of the skin, damage to the gills and kidneys and even retardation of fish growth (Soderberg, 1994). Because anesthetics decrease the metabolic activity of fish, it is believed that their addition to the water can reduce the rate of ammonia excretion, thereby improving the water quality (Oliveira et al., 2009). However, in this study, no significant differences in ammonia concentration were found between the different treatments at each salinity level. A study conducted by Inoue et al. (2005) reported that the addition of clove oil $\left(5 \mathrm{mg} \mathrm{L}^{-1}\right)$ during the transport of matrinxã (Brycon amazonicus) did not elicit significant effects on ammonia concentrations, despite its efficacy at reducing the stress response of fish during transport.

According Sampaio et al. (2002), salinity elicits a direct effect on water quality. Saltwater has more dissolved ions than freshwater, and these ions facilitate the oxidation of organic compounds, such as ammonia and the ammonium ion. This process results in higher nitrite levels in saltwater compared with freshwater.

The differential toxicity of nitrite in different species depends on its rates of accumulation. However, particular features of the water might also influence toxicity (Sampaio et al., 2002). Russo et al. (1981) observed that although seawater has increased nitrite levels, nitrite toxicity to fish in seawater is decreased. Fish secrete mucus on the parts of their bodies that come in contact with salt, thus providing a greater physical barrier against increased nitrite concentrations. Similar results were also described by Sampaio et al. (2002) in experiments using Mugil platanus.

In this study, the dissolved oxygen concentrations were similar among all of the treatments. This finding can likely be attributed to the fact that the bags were inflated and pressurized with oxygen before shipping, thus rendering the oxygen concentrations consistently high or even near saturation at different salinities.

The concentrations of body sodium and potassium found in this study were similar to those previously reported by Gomes et al. (1999), who assessed the effects of salt in the water used for transporting silver catfish (Rhamdia quelen). The total body sodium concentrations in the fish increased according to the increase in water salinity, although the potassium levels did not differ significantly among the salinities. The main explanation for this result is the long time previous acclimation of the fish to the same salinity of their transportation, which lead the fish to regulate their salts contents according to the medium.

When stress disturbs the ability of a fish to osmoregulate, the ionic composition of its blood begins to resemble that of the surrounding medium. Transportation-induced stress increases gill permeability to water and leads to changes in plasma electrolytes in hyperosmotic and hypoosmotic environments (Carneiro et al., 2007). Carneiro and Urbinati (2001) found a significant decrease in blood sodium levels with increase of benzocaine concentration after matrinxã transport in freshwater and attribute the fish mortality to the 
loss this ion. In the present study, no significant differences in the total body ions of the fish were observed among the groups transported at different menthol concentrations. Therefore, the tested menthol concentrations did not cause an osmorregulatory disturbance in juvenile fat snook.

Menthol is a suitable anesthetic for juvenile fat snook (around $1.5 \mathrm{~g}$ ) when it is applied at concentrations of 37 or $50 \mathrm{mg} \mathrm{L}^{-1}$ for short-term handling or deep anesthesia, respectively, regardless of salinity. Conversely, menthol does not influence the measured water parameters and body ions, and it is not necessary for the transport of fat snook.

\section{Acknowledgements}

This work was supported by CNPq grants \#559090/2009-9 and $\# 562821 / 2010-4$ as well as FAPES grant $\# 53235282 / 2011$. L.C. Gomes is the recipient of a researcher fellowship from $\mathrm{CNPq} / \mathrm{Brazil}$.

\section{References}

AMERICAN PUBLIC HEALTH ASSOCIATION - APHA. AMERICAN WATER WORKS ASSOCIATION, WATER ENVIRONMENT FEDERATION, 1998. Standard methods for the examination of water and wastewater. 19th ed. Washington: APHA.

CARNEIRO, P.C.F., URBINATI, E.C. and BENDHACK, F., 2007. Osmoregulation and fish transportation. In: B. BALDISSEROTTO, J.M. MANCERA. and B.G. KAPOOR, eds. Fish osmoregulation. New Hampshire: Science Publishers. pp. 235-248.

CARNEIRO, P.C.F. and URBINATI, E.C., 2001. Plasma electrolyte disturbance in matrinxä, Brycon Cephalus transported under influence of benzocaine. Journal of Applied Aquaculture, vol. 11, pp. 1-13. http://dx.doi.org/10.1300/J028v11n04_01.

CERQUEIRA, V.R., 2010. Cultivo do robalo-peva (Centropomus parallelus). In B. BALDISSEROTTO, and L.C. GOMES, eds. Espécies nativas para piscicultura no Brasil. 2nd ed. Santa Maria: Editora da UFSM. pp. 489-520.

FAÇANHA, M.F. and GOMES, L.C., 2005. A eficácia do mentol como anestésico para tambaqui (Colossoma macropomum: characiformes: characidae). Acta Amazonica, vol. 35, no. 1, pp. 71-75. http://dx.doi.org/10.1590/S0044-59672005000100011.

GHAZILOU, A., HASANKANDI, H.S., CHENARY, F., NATEGHI, A., HAGHI, N. and SAHRAEEAN, M.R., 2010. The anesthetic efficiency of clove oil in caspian salmon, Salmo trutta caspius $\mathrm{k}$., smolts in dosage-salinity-pH linked approach. Journal of the World Aquaculture Society, vol. 41, no. 4, pp. 655-660. http:// dx.doi.org/10.1111/j.1749-7345.2010.00407.x.

GOMES, L.C., CHIPPARI-GOMES, A.R., LOPES, N.P., ROUBACH, R. and ARAUJO-LIMA, C.A.R.M., 2001. Efficacy of benzocaine as an anesthetic in juvenile tambaqui Colossoma macropomum. Journal of the World Aquaculture Society, vol. 32, no. 4, pp. 426-431. http://dx.doi.org/10.1111/j.1749-7345.2001.tb00470.x.

GOMES, L.C., GOLOMBIESKI, J.I., CHIPPARI-GOMES, A.R. and BALDISSEROTTO, B., 1999. Effect of salt in the water for transport on survival and on $\mathrm{na}^{+}$and $\mathrm{k}^{+}$body levels of silver catfish, Rhamdia quelen, fingerlings. Journal of Applied Aquaculture, vol. 9, no. 4, pp. 1-9. http://dx.doi.org/10.1300/J028v09n04_01.
INOUE, L.A.K.A., SANTOS-NETO, C. and MORAES, G., 2003. Clove oil as anaesthetic for juveniles of matrinxã Brycon cephalus (gunther, 1869). Ciência Rural, vol. 33, no. 5, pp. 943-947. http:// dx.doi.org/10.1590/S0103-84782003000500023.

INOUE, L.A.K.A., AFONSO, L.O.B., IWAMA, G.K. and MORAES, G., 2005. Efeitos do óleo de cravo na reposta de estresse do matrinxã (Brycon cephalus) submetido ao transporte. Acta Amazonica, vol. 35, no. 2, pp. 943-947. http://dx.doi.org/10.1590/ s0044-59672005000200018.

ISMIÑO-ORBE, R.A., ARAUJO-LIMA, C.A.R.M. and GOMES, L.C., 2003. Ammonia excretion by tambaqui (Colossoma macropomum) related to water temperature and fish mass. Pesquisa Agropecuaria Brasileira, vol. 38, pp. 1243-1247. http://dx.doi. org/10.1590/s0100-204x2003001000015.

OLIVEIRA, J.R., CARMO, J.L., OLIVEIRA, K.K.C. and SOARES, M.C.F., 2009. Cloreto de sódio, benzocaína e óleo de cravo-da-índia na água de transporte de tilápia-do-nilo. Revista Brasileira de Zootecnia, vol. 38, no. 7, pp. 1163-1169. http:// dx.doi.org/10.1590/S1516-35982009000700001.

PRODOCIMO, V. and FREIRE, C.A., 2006. The $\mathrm{Na}^{+}, \mathrm{k}^{+}, 2 \mathrm{Cl}^{-}$ cotransporter of estuarine pufferfishes (Sphoeroides testudineus and S. greeleyi) in hypo- and hyper-regulation of plasma osmolality. Comparative Biochemistry and Physiology, vol. 142, no. 3-4, pp. 347-355. PMid:16469544.

ROSS, L.G. and ROSS, B., 1999. Anaesthetic and sedative techniques for aquatic animals. Oxford: Blackwell Science.

ROUBACH, R., GOMES, L.C., FONSECA, F.A.L. and VAL, A.L., 2005. Eugenol as an efficacious anaesthetic for tambaqui, Colossoma macropomum (cuvier). Aquaculture Research, vol. 40, no. 11, pp. 1056-1061. http://dx.doi.org/10.1111/j.13652109.2005.01319.x.

RUSSO, R., THURSTON, K.R. and EMERSON, K., 1981. Acute toxicity of nitrite to rainbow trout (Salmo gairdneri): effects of $\mathrm{pH}$, nitrite species, and anion species. Canadian Journal of Fisheries and Aquatic Sciences, vol. 38, no. 4, pp. 387-397. http://dx.doi. org/10.1139/f81-054.

SAMPAIO, L.A., WASIELESKY, W. and MIRANDA-FILHO, K.C., 2002. Effect of salinity on acute toxicity of ammonia and nitrite to juvenile Mugil platanus. Bulletin of Environmental Contamination and Toxicology, vol. 68, no. 5, pp. 668-674. http:// dx.doi.org/10.1007/s001280306. PMid:12068932.

SIMÕES, L.N. and GOMES, L.C., 2009. Eficácia do mentol como anestésico para juvenis de tilápia-do-nilo (Oreochromis niloticus). Arquivo Brasileiro de Medicina Veterinária e Zootecnia, vol. 61, no. 3, pp. 613-620. http://dx.doi.org/10.1590/S010209352009000300014.

SIMÕES, L.N., LOMBARDI, D.C., GOMIDE, A.T.M. and GOMES, L.C., 2011. Efficacy of clove oil as anesthetic in handling and transportation of nile tilapia, Oreochromis niloticus (Actinopterygii: cichlidae) juveniles. Zoologia, vol. 28, no. 3, pp. 285-290. http://dx.doi.org/10.1590/S1984-46702011000300001.

SMALL, B.C., 2003. Anaesthetic efficacy of metomidate and comparison of plasma cortisol responses to tricaine methanesulfonate, quinaldine and clove oil anesthetized channel catfish ictalurus punctatus. Aquaculture Research, vol. 218, no. 1-4, pp. 177-185. http://dx.doi.org/10.1016/S0044-8486(02)00302-2.

SODERBERG, R.W., 1994. Flowing water fish culture. Boca Raton: CRC Press. 
SOUZA, R.A.R., CARVALHO, C.V.A., NUNES, F.F., SCOPEL, B.R., GUARIZI, J.D. and TSUZUKI, M.Y., 2012. Efeito comparativo da benzocaína, mentol e eugenol como anestésicos para juvenis de robalo peva. Boletim do Instituto de Pesca, vol. 38, pp. 247-255.

STOSKOPF, M., 1993. Anaesthesia. In: L. BROWN, ed. Aquaculture for veterinarians: fish husbrandry and medicine. London: Pergamon Press. pp. 161-168. Pergamon Veterinary Handbook Series.

TONDOLO, J., AMARAL, L.P., SIMÔES, L.N., GARLET, Q.I., SCHINDLER, B., OLIVEIRA, T.M., SILVA, B.F., GOMES, L.C.,
BALDISSEROTTO, B., MALLMANN, C.A. and HEINZMANN, B.M., 2013. Anesthesia and transport of fat snook Centropomus parallelus with the essential oil of Nectandra megapotamica (spreng.) Mez. Neotropical Ichthyology, vol. 11, no. 3, pp. 667674. http://dx.doi.org/10.1590/S1679-62252013000300020.

TSUZUKI, M.Y., SUGAI, J.K., MACIEL, J.C., FRANCISCO, C.J. and CERQUEIRA, V.R., 2007. Survival, growth and digestive enzyme activity of juveniles of the fat snook (Centropomus parallelus) reared at different salinities. Aquaculture (Amsterdam, Netherlands), vol. 271, no. 1-4, pp. 319-325. http://dx.doi. org/10.1016/j.aquaculture.2007.05.002. 